Article

\title{
Religious Diversity in the Public Sphere: The Canadian Case
}

\author{
Lori G. Beaman
}

Department of Classics and Religious Studies, University of Ottawa, Ottawa, ON K1N6N5, Canada; lbeaman@uottawa.ca

Received: 6 October 2017; Accepted: 18 November 2017; Published: 27 November 2017

\begin{abstract}
This paper analyzes the contours of religious and nonreligious diversity in the Canadian public sphere. The ever-changing (non)religious landscape offers an opportunity to consider the flow of ideas from this new diversity to responses and choices at the individual, group, and state levels to inclusion and exclusion. The paper first begins with a descriptive approach to religious diversity, identifying the normatively-charged nature inherent to measures of religion. It then turns to the notion of choices, considering the somewhat uniquely Canadian contributions of multiculturalism, reasonable accommodation, and the recent complication of nonreligion as a category of religious identity. The paper then considers three case studies which reveal the tensions embedded in the new diversity and responses to it in Canada, including (1) the Saint-Sacrement Hospital crucifix incident; (2) Zunera Ishaq's challenge to the citizenship ceremony niqab ban; and (3) school controversies in Ontario's Peel Region.
\end{abstract}

Keywords: religion; nonreligion; nones; diversity; reasonable accommodation; multiculturalism; identity; exclusion; inclusion; deep equality

\section{Introduction}

Although there is debate about precisely what is occurring, there is little doubt that the religious landscape is changing. Words like 'postsecular', 'postChristian', 'superdiversity' and 'secularization' have attempted to capture some of this change, but none are fully able to address the complexity of contemporary (non)religion. During the past seven years I have led the Religion and Diversity Project which is based in Canada. The stated aim of that project is to address the following question: What are the contours of religious diversity in Canada and how can we best respond to the opportunities and challenges presented by religious diversity in ways that promote a just and peaceful society? Specifically, the project investigates the following questions: (1) How are religious identities socially constructed? (2) How is religious expression defined and delimited in law and public policy? (3) How and why do gender and sexuality act as flashpoints in debates on religious freedom? (4) What are alternative strategies for managing religious diversity?

The project's main contribution is to identify in detail the contours of religious diversity in Canada and the potential benefits of approaches to diversity that promote substantive or deep equality and move beyond tolerance and accommodation. Our comparative research places Canada in the context of other Western democracies and identifies global patterns in responses to religious diversity. This research programme presents diversity not primarily as a problem, but as a resource to propose strategies for equality that will advance knowledge and enhance public policy decision-making. This paper considers diversity in the context of that project, bringing it into conversation with the goals of the editors in considering the flow of ideas from new diversity to responses and choices at individual, group, and state levels to inclusion and exclusion. What does diversity look like in Canada? I'll begin with a descriptive approach to religious diversity, aware that even measures of religion 
are normatively charged. I'll then turn to the notion of choices, considering the somewhat uniquely Canadian contributions of multiculturalism, reasonable accommodation, and the recent complication of nonreligion as a category of religious identity. The paper then considers several case studies which reveal the tensions embedded in the new diversity and responses to it in Canada.

\section{Diversity as Description}

Diversity and pluralism are sometimes used interchangeably, and sometimes as separate concepts. Pluralism is laden with problems that are inherited in part from political science. Though American political theorist William Connolly (2005) has attempted to reclaim pluralism from the clutches of normatively conservative thinkers, we need to be cautious about its use, always being clear about how we are using it and asking whether it is laying claim to a particular version of social cohesion that is exclusive rather than inclusive. ${ }^{1}$ For this reason, diversity too is never fully normatively neutral—who is measured and how, or 'who counts' is a normatively-laden exercise. Beckford notes the tendency to lump together "religious diversity, the degree of acceptance of certain religions in the public sphere, and the ideological commitment to the value of religious diversity and the increasing scope of religious acceptability" (Beckford 2003, p. 100) under the rubric of pluralism.

With these caveats in mind, a review of Canadian statistics reveals the ever-evolving religious and nonreligious landscape in Canada, driven in part by a consistently foreign-born population over the past 150 years. In $1871,16.1 \%$ of the population was foreign-born, while in $201120.6 \%$ of the population was foreign-born, and in 2016 this percentage rose to 21.9\% (See Statistics Canada 2016, 2017). Over time the percentage of those who are Christian has decreased, resulting in expanded numbers of minority religious groups (see Beyer and Ramji 2013). (Table 1)

Table 1. Religion in Canada ${ }^{2}$.

\begin{tabular}{cccc}
\hline Religion & $\mathbf{1 9 9 1}$ & $\mathbf{2 0 0 1}$ & $\mathbf{2 0 1 1}$ \\
\hline Buddhist & $0.6 \%$ & $1 \%$ & $1.1 \%$ \\
Muslim & $0.9 \%$ & $2 \%$ & $3.2 \%$ \\
Hindu & $0.6 \%$ & $1 \%$ & $1.5 \%$ \\
Sikh & $0.5 \%$ & $0.9 \%$ & $1.4 \%$ \\
Jewish & $1.2 \%$ & $1.1 \%$ & $1.0 \%$ \\
Nones & $12.3 \%$ & $16.2 \%$ & $23.9 \%$ \\
Christian & $82.8 \%$ & $76.6 \%$ & $67.3 \%$ \\
Indigenous Spiritualities $\left({ }^{3}\right)$ & - & - & $0.2 \%$ \\
\hline
\end{tabular}

The key point here is that diversity is increasing, but that change is a matter of degree-Canada has always been diverse. Moreover, some categories are complicated: the colonial impulse to convert has meant that amongst Indigenous populations, Christianity ${ }^{4}$ and Indigenous spiritualities reside

1 Connolly writes, "In the argument between neoconservatives and liberal nationalists over equality, the former hold too many cards. It seems to me that they will continue to do so until we develop the idea of a thick network pluralism that exceeds both shallow, secular models of pluralism and the thick idea of the highly centered nation. Liberal images of the procedural nation are not only insufficient in themselves, they tend to collapse under pressure from rightist orientations to the nation that are more thick and dense" (Connolly 2005, p. 8).

3 In the 1991 and 2001 Censuses, Indigenous Spiritualties were not evaluated on their own, but rather lumped into "Other Religions" alongside those who identified as Pagan, Wicca, Unity-New Thought-Pantheist, Scientology, Rastafarian, New Age, Gnostic, and Satanist.

2 See Statistics Canada 2001, 2011.

4 In 2015, the Truth and Reconciliation Commission of Canada released its final report detailing the tragic legacy of Canada's residential school system. The report and its Calls to Action ask the government and Christian church parties to acknowledge their role in the colonization of Indigenous peoples in Canada and to engage in an ongoing process of reconciliation. See Honouring the Truth, Reconciling for the Future: Summary of the Final Report of the Truth and Reconciliation Commission of Canada. Retrieved from http:/ / www.trc.ca/websites/trcinstitution/index.php? $\mathrm{p}=890$. 
side by side, making 'what is your religion?' a difficult question to answer. ${ }^{5}$ Religion is often "cobbled together," as William Closson James argues, pointing to a need for "new terminology and more sophisticated analyses for consideration of the current and differing methods by which non-syncretistic combinations of religions with one another are taking place" (James 2012, p. 55). Nonetheless, degree matters and it is arguably producing a change in kind, having reached a critical point that is creating a new diversity.

This new diversity has been characterized by Steven Vertovec as 'superdiversity', a model which rejects a unidimensional measure of diversity (ethnicity) to insist on additional dimensions such as: "differential immigration statuses and their concomitant entitlements and restrictions of rights, divergent labour market experiences, discrete gender and age profiles, patterns of spatial distribution, and mixed local area responses by service providers and residents. Rarely are these factors described side by side" (Vertovec 2007, p. 1025; see also Vertovec 2010, 2011). Entailing descriptive, methodological and policy implications (Meissner and Vertovec 2015, p. 542-43), the idea that diversity has become more complex certainly holds in Canada, including the majority-minority reality of some cities (especially Toronto) (see Crul 2015; Meissner 2016). ${ }^{6}$ For example, StatsCan reports that "In 2011, Canada had a foreign-born population of about $6,775,800$ people. They represented $20.6 \%$ of the total population, the highest proportion among the G8 countries" (Statistics Canada 2013b). Five years later, " $21.9 \%$ of the population reported they were or had ever been a landed immigrant or permanent resident in Canada. This proportion is close to the $22.3 \%$ recorded during the 1921 Census, the highest level since confederation" (Statistics Canada 2017). Whether one embraces Vertovec's 'superdiversity' approach or not, the fact remains that diversity has taken on a new shape that requires a rethinking of analytical approaches to diversity generally and religion specifically.

Beckford has proposed that diversity be conceptually sorted into (1) the empirical forms of diversity in relation to religion; (2) normative positions about the value of diversity; (3) legal and social policies regulating religion; and (4) "relational contexts of everyday interactions between individuals and groups identified as religious" (Beckford 2014, p. 16). Thus, rather than characterize the nature of diversity Beckford proposes a conceptual map that captures the essential analytical elements that are necessary to the achievement of social inclusion. Moreover, this conceptualization slides nicely between the public and the private, which is itself a rather fluid divide. It is from here that we can move to some features of the Canadian landscape in relation to religion in the public sphere.

\section{Diversity and the Public Sphere in Canada}

Three aspects of the Canadian context are especially pertinent to a consideration of religious diversity in the public sphere ${ }^{7}$ : multiculturalism, reasonable accommodation, and the growth of the 'none' category and the accompanying complication of the measurement of (non)religious identity.

5 Bramadat and Seljak (2008) write, "It is still the case that the vast majority of Aboriginals would say they are Christians of one denomination (or tradition) or another, even while some of them may also embrace traditional Aboriginal spiritual beliefs, values, and practices. In fact, there are no definiteive studies to establish exactly how many Canadian Aboriginals consider themselves to be Christians. However, when we ask colleagues who specialize in Aboriginal religions and cultures to estimate the approximate percentage of Aboriginals who would likely identify themselves as Christian, the estimates range from 70 to 85 per cent" $(2008$, p. 428$)$.

6 See De Bock (2014) for criticisms relating to the unavailability of data regarding super-diversity's many dimensions and Padilla et al. (2015) on the methodological challenges of conducting comparative work using super-diversity.

7 Defining what constitutes the public sphere is challenging. While Habermas (2006) article "Religion in the Public Sphere" sparked academic discussion around the 'public sphere', he does not actually specify what is meant by the term in that piece. Only back in a 1996 article did he detail that "The public sphere can best be described as a network for communicating information and points of view (i.e., opinions expressing affirmative or negative attitudes); the streams of communication are, in the process, filtered and synthesized in such a way that they coalesce into bundles of topically specified public opinions. Like the lifeworld as a whole, so, too, the public sphere is reproduced through communicative action, for which mastery of a natural language suffices; it is tailored to the general comprehensibility of everyday communicative practice" (Habermas 1996, p. 360). Furseth (2017) is an excellent example of a multi-faceted approach to the study of religion in the public sphere. 


\subsection{Multiculturalism}

Multiculturalism is supported in Canada at the level of policy, public opinion (see Adams 2007), legislatively by the Multiculturalism Act, and constitutionally by section 27 of the Canadian Charter of Rights and Freedoms, which states, "This Charter shall be interpreted in a manner consistent with the preservation and enhancement of the multicultural heritage of Canadians." Like diversity, multiculturalism has a range of meanings: it may simply be a descriptor of a demographic reality ('we live in a multicultural society'); it may signal an ideology; and it must also always be critically evaluated to determine who is using it for what purposes. In response to recommendations made by the Royal Commission on Bilingualism and Biculturalism in 1969, the federal government introduced its multiculturalism policy in 1971. The Commission had recommended a shift away from assimilation to the integration of non-Indigenous, non-French, and non-English ethnic groups into Canadian society. Prime Minister Pierre Elliott Trudeau introduced the multiculturalism policy and stated, "the individual's freedom would be hampered if he were locked for life within a particular cultural compartment by the accident of birth or language" (as quoted in Ryan 2010, p. 12). In 1972, a Multicultural Directorate was established within the Department of Secretary of State to implement the government's new policy, with a Ministry of Multiculturalism arriving in 1973 to more fully oversee the implementation (Dewing 2013, p. 3). Not everyone welcomed the turn toward multiculturalism. In Québec, for example, it has been seen by some as a subversion of the recognition of the importance of the French as a founding people. This objection has manifested partially by the development of the concept of interculturalism, though this may be largely a concept that exists at the level of intellectual elites rather than at the grassroots level. Gérard Bouchard has been the primary author and proponent of interculturalism, which seeks to preserve the priority of majority culture and to achieve the integration of minorities within a majority-preserving framework. It is perhaps not surprising then that Québec is the place where reasonable accommodation moved most pervasively beyond the courts and into public discourse. ${ }^{8}$

While in Europe multiculturalism has become a rather dirty word, in Canada it has retained its currency after suffering a decade long decline under a conservative government (which itself mobilized the notion toward the end of its mandate). The 'decline' of multiculturalism has been much debated and discussed elsewhere (see Vertovec and Wessendorf 2010), but in Canada the discussion has taken a different shape, primarily between critics and supporters. ${ }^{9}$ More recently, critics have noted the failures of Canada vis-à-vis its Indigenous population (see Hansen 2017); the limits of multicultural tolerance (Mudde 2016; Levin et al. 2015); its potential incompatibility with liberal values ( $\mathrm{Ng}$ and Bloemraad 2015); differences in perceptions about what multiculturalism is and authorizes (Thurairajah 2017); and the changing meaning of multiculturalism from 'about us' to 'about them' (Winter 2011, 2015) that has potentially divisive effects rather than creating a framework for inclusion. Nonetheless, it is quite possible that the 'end' of multiculturalism simply can't hold currency in Canada because it is enshrined in the Charter and is mentioned by the courts, though most often as a demographic reality rather than an ideology. ${ }^{10}$

The fact remains that, like diversity, multiculturalism must be understood as a socially constructed category, ranging in meaning from a demographic reality, an ideology, and a series of policies and laws. As Phil Ryan puts it, "[t]he wide range of uses to which 'multiculturalism' is put reflects the richness of its suffix" (Ryan 2010, p. 7). Despite the criticisms, it remains a strong part of national discourse and has

8 Gérard Bouchard defines interculturalism as a pluralist model unique to Québec that "concerns itself with the interests of the majority culture, whose desire to perpetuate and maintain itself is perfectly legitimate, as much as it does with the interests of minorities and immigrants-we thus find no reason to oppose either the defenders of the identity and traditions of the majority culture on one side, or the defenders of the rights of minorities and immigrants on the other; it is both possible and necessary to combine the majority's aspirations for identity with a pluralist mindset, making for a single process of belonging and development" (Bouchard 2011, pp. 438-39).

9 See Markell 2003; Bannerji 2001; Day 2000; Kernerman 2005; Kymlicka 1995, 2005, 2011; Ryan 2010, 2016 ; Adams 2007.

10 See S.L. $v$ Commission scolaire des Chênes, 2012 SCC 7, [2012] 1 SCR 235. 
both the potential to unify, protect minorities, and to create silos (Nayar 2012). In terms of its impact on religion, it is difficult to measure. Partly this is because of a tendency to exclude religion as a variable from the rubric of conversations and research about multiculturalism (Bramadat 2008). However, in his research on atheism, for example, Steven Tomlins found that when asked about whether they felt free to express their atheism in Canada, his atheist study participants said "yes" and in some instances explicitly associated that with the fact that Canada is a multicultural country (Tomlins 2010, 2015). It may be, therefore, that the ideology of multiculturalism has created a sense of inclusion across difference (see also Winter 2011, 2015; Adams 2007; Ryan 2016). In the Immigrant Youth study, Beyer found that attitudes toward multiculturalism were generally positive, although his study participants believed that it was not always implemented the way it should be (Beyer 2013, p. 57-69). In sum, multiculturalism plays an important role in thinking about diversity in the public sphere in Canada - whether mentioned explicitly or through its presence as a narrative of Canadian identity for a half century, it is a contextualizing factor that cannot be overlooked.

\subsection{Reasonable Accommodation}

As with multiculturalism, the idea that difference should be accommodated has come to be part of the public conversation around religion in Canada. Indeed, reasonable accommodation has taken primary place as the framework within which diversity should be managed. Initially limited to a relatively narrow realm of law, reasonable accommodation has expanded within law, ${ }^{11}$ but, more importantly, has moved to the public sphere as a socially viable way to talk about diversity and religion in the public sphere. ${ }^{12}$ This expansion became especially pronounced in the period after the completion of the Bouchard-Taylor Commission and the release of its report (see Bouchard and Taylor 2008). Following a Supreme Court of Canada decision (Multani ${ }^{13}$ ) in 2006, the Québec government struck the Bouchard-Taylor Commission to investigate and address public anxiety surrounding 'too much accommodation' in Québec society, as well as the implications of reasonable accommodation on social cohesion. The Multani case, in which the Supreme Court held that a Sikh schoolboy had the right to wear his kirpan to school, was one catalyst for the creation of the Commission. Co-chaired by philosopher Charles Taylor and sociologist Gérard Bouchard, the Commission held public hearings and received 900 briefs from groups and individuals expressing their views on diversity and religion in Québec. In its 300-page report, the Commission found that much of the social panic around 'too much accommodation' had been exaggerated and unfounded.

I have written elsewhere about the problems with reasonable accommodation, which I argue preserves a hierarchy of an 'Us' who accommodates 'Them' and leaves little space for a genuine or deep equality (See Beaman 2011, 2012, 2013, 2014, 2017). My concern is not focused primarily on law, but with the circulation of reasonable accommodation as a social regulator of diversity. To be sure, the legal implementation of reasonable accommodation may be the foundation for the social migration of the concept, but that is beyond the scope of the discussion here (See Fokas 2015). Reasonable accommodation has a number of effects: it positions an 'Us' as accommodating an 'Other', maintaining a hierarchy of privilege that does little to achieve inclusion or equality. It produces a discourse of demand, "the notion of religious differences that underpins this discourse produces

11 Compare, for example, the Supreme Court of Canada's grappling with accommodation and the section 1 balancing test in Multani v Commission scolaire Marguerite-Bourgeoys, 2006 SCC 6 and Alberta v Hutterian Brethren of Wilson Colony, 2009 SCC 37. See Beaman (2017, pp. 134-36) for more on this point.

12 In Canada, the beginnings of a legal discourse of reasonable accommodation emerged in the 1980s: see Day and Brodsky (1996) for a thorough discussion of early reasonable accommodation cases. See also Woehrling 1998. Jolls (2001) has considered the relationship between the requirement for accommodation and anti-discrimination law. See also Williams and Segal 2003, Sheppard 2010, and Choudhry 2013.

13 The Multani case involved a school forbidding a Sikh boy from carrying his kirpan to school. The Supreme Court upheld Gurbaj Singh Multani's right to carry the kirpan to school under conditions that the kirpan be concealed in a sewn-shut sheath. 
an image of religious minorities (especially Muslims) as 'rigid' requesters, differentiating them from 'flexible' institutions. Requesting, therefore, becomes a central component to how these minorities are imagined to act, and becomes at the same time a way to locate and delimit their religiosity" (Barras 2016, p. 68). The requesting individual or group is in turn compelled to express gratitude for the favour bestowed through the 'granting' of accommodation.

The language of accommodation as a tool for diversity management has expanded beyond the borders of Canada into Belgium, Britain, France, and Europe more generally. ${ }^{14}$ Waddington (2011), Bribosia et al. (2009), Gibson (2013), Alidadi (2012), and Martínez-Torrón (2014) all advocate for some version of reasonable accommodation in Europe. It continues to circulate in Canada as the primary language for the management of religious diversity.

\section{3. (Non)Religious Identity}

Though not unique to Canada, the rise of the number of people self-describing as nonreligious or 'nones' has raised a new complication in the study of diversity. ${ }^{15,16}$ What happens when a sizeable portion of the population has no religion or is indifferent (Quack and Schuh 2017). to religion, an identity category that is on the other hand very important to others? Moreover, how then to reshape social institutions to reflect and respond to this new reality? Further, religious identity itself is in need of refined measurement tools that better reflect changes in religious identity over the life course and that leave space for complex affiliations and multiple practices. As Beyer et al. (2016) point out, the measurement of religious identity has relied on four assumptions-that religion is institutional, looks like Abrahamic religion, is possible only in singular rather than plural forms, and is to be assessed against standardized orthopraxy/doxy terms (Beyer et al. 2016, p. 10). To this end, the Religion and Diversity Project has prioritized the development of new measures of religious identity, not solely to address the issue of nonreligion, which is probably best measured obliquely through practices such as end-of-life rituals, but also to capture the shifts in religious practice and identity that occur over the life course. This presents particular challenges as it requires either that we rely on individuals' memories for their life course journey around religion, or that we interview over the life course. We believe the latter is a more reliable strategy, but it requires significant resources to accomplish. In the course of this research we will access shifting self-conceptualizations, including moves from religious to nonreligious and the opposite trajectory as well.

In addition to individual trajectories, there are contextual differences as well. In Canada, nonreligion is different across the country. In 2011, those with "no religious affiliation" was highest in the provinces of Ontario and British Columbia: approximately 21.1\% of Toronto's population and $41.5 \%$ of Vancouver's population were declared to have no religious affiliation (Statistics Canada 2013b). Trends of "disaffiliation" are progressing at a more rapid pace in British Columbia (moving from $13 \%$ to $44 \%$, from 1971 to 2011 ), the Prairies (5\% to $29 \%$ ), and Ontario (jumping from $5 \%$ to $23 \%$ ). Rates are slower in the Atlantic provinces, rising from $2 \%$ to $16 \%$ over the same four-decade period, while Québec shows the slowest increase of disaffiliation, moving from 1\% to $12 \%$ (Pew Forum on Religion and Public Life 2013).

14 On the Belgian context, see Bribosia et al. 2010, 2011. On Britain, see Modood (2005). See Laborde (2009) on the potential for reasonable accommodation in France.

15 The rise of the nones can be tracked globally: Canada (23.9\%), the USA (19.6\%), Australia (22.3\%), the UK (46\%), France (28\%), the Czech Republic (76.4\%), Estonia (59.6\%), Sweden (27\%), Hong Kong (56\%), China (52\%), North Korea (71\%), and Japan (57\%): see Statistics Canada (2013a); Pew Forum on Religion and Public Life (2012a; 2012b, pp. 45-50); YouGov (2016); Woodhead (2017); Australian Bureau of Statistics (2013); and Zuckerman (2010). According to WIN-Gallup International (2012), over half of the populations in Vietnam, France, and Ireland consider themselves "not a religious person" or atheist.

16 For an in-depth discussion of what nonreligion looks like for some Canadians, see Thiessen 2015. See Wilkins-LaFlamme 2015 for a quantitative analysis of 'nones' in Canada. For historically situated discussions of nonreligion see Block 2017 and Marks 2017. 
Similarly, there are some age differences between those who identify as nones: they are likely to be younger, with $29 \%$ of those aged $25-44$ having no religious affiliation, compared to $20 \%$ of those aged $45-64$ and 12\% of those 65 and older (Pew Forum on Religion and Public Life 2013). Though age difference is important in self-described nonreligion, I believe that focusing only on youth for insight into nonreligion misses a vital part of the picture. As, for example, baby boomer women transition into retirement, their nonreligion is potentially an important force in social change: they are the most professionally skilled group of Western women in history, they are more affluent, and many of them are setting their sights on making a difference (again — they were also responsible for second wave feminism) turning to social justice causes, including the environment, creating livable urban spaces, and political activism. This is not to say that these things can't be and aren't accomplished within religion, but increasing numbers of these powerful women have given up spending their energy keeping churches afloat and are turning their attention elsewhere. Thus, in short, greater attention needs to be paid to nonreligion at all ends of the age spectrum.

With these contextualizing factors in mind, we now turn to a consideration of religious diversity and the public sphere drawing on three examples.

\section{Case Studies}

The purpose of these case studies is to briefly review some of the ways that discourses about diversity intersect with responses at individual, group and institutional levels and can signal inclusion or exclusion, or, perhaps both. The case studies below don't cover all of the issues related to diversity in the public sphere in Canada, but they do offer a sense of some of the debates and contests that arise around religion and nonreligion.

\subsection{Saint-Sacrement Hospital}

In February 2017, after receiving a complaint from an undisclosed source, the board of the Saint-Sacrement hospital in Québec City, Canada, removed a crucifix from the front entry of the lobby of the hospital. The crucifix hung between two elevators above eye level. The hospital intended to return the crucifix to the Sisters of Charity, the religious order which had founded the hospital. Reports of the motivation behind the removal of the crucifix vary. One said that it was influenced by the decision of the Supreme Court of Canada in the Saguenay ${ }^{17}$ case. Another version was that it was to bring hospital practice in line with Bill 62, which proposes to set out guidelines on religious neutrality and accommodation for organizations. The religious neutrality of the state was also cited as a possible motivation. The hospital's statement justifying the removal of the crucifix noted the following:

Since our primary mission is to provide health care and services, we must first and foremost respect the rights of our patients, who are somehow captive to the institution. In this regard, the Commission on Human Rights and Freedoms has a clear position: [The] presence in a public institution of a religious symbol, such as a crucifix or a cross, does not raise a particular problem from the point of view of the Charter, unless that symbol acquires a coercive character because of the context in which it is inscribed. Thus, when the clientele of the institution is vulnerable, because it is captive, young or influential, such as in a school, for example, exposure to a religious symbol, such as a cross hanging on the wall, may be incompatible with the rights and freedoms of the person. ${ }^{18}$

17 Mouvement laïque québécois v Saguenay (City), 2015 SCC 16 [Saguenay].

18 Translation provided by Christine L. Cusack. Original French reads: "Comme la mission première de notre établissement est de donner des soins et services de santé, nous nous devons de respecter en premier lieu les droits de nos patients, lesquels sont en quelque sorte captifs de l'institution. À cet égard, la Commission des droits et libertés de la personne et des droits de la jeunesse a une position claire : [La] présence dans une institution publique d'un symbole religieux, tel qu'un crucifix ou une croix, ne soulève pas de problème particulier du point de vue de la Charte, à moins que ledit symbole n'acquière un caractère coercitif en raison du contexte dans lequel il s'inscrit. Ainsi, lorsque la clientèle de l'institution est vulnérable, parce que captive, jeune ou influençable, comme dans une école, par exemple, alors l'exposition à un symbole 
The language of those who objected to the removal of the crucifix in the brouhaha that ensued was dominated by words like 'culture' and 'heritage'. ${ }^{19}$ Hardly anyone spoke about religion. Rather than defend the crucifix drawing on its religious qualifications, the public debate and discussion focused almost entirely on culture, heritage, and the meaning of the neutrality of the state. When religion was mentioned, it was linked to heritage and culture. A petition to reinstate the crucifix circulated on Facebook stated:

in the current context of respecting the religions that settle in Québec, some feel that the traditions of long-established people are being questioned. All religions must be respected and the Christian religion is one of them. These people are entitled to demand respect for their culture, traditions and religion, even if it is purely a patrimonial one.

Following the removal of the crucifix, the hospital received 'credible threats' against it and its personnel (a man was arrested but not charged), as well as 600 phone calls. Various political figures expressed their opinions about the cultural and heritage value of the crucifix, putting pressure on the hospital to return it to its rightful place. The Minister of Health became involved, at first saying he wasn't interested in telling the hospital what to do, but then did an about-face, saying that "It's behaviour similar to Russia in 1917." (Hamilton 2017) The group Mouvement Tradition Québec entered the hospital and put up its own crucifix (which was taken down). Archbishop Cardinal Gérald Cyprien Lacroix expressed disappointment over the removal of the crucifix.

The crucifix was eventually reinstated, with the hospital alleging the Ministry of Health had demanded its return, though the ministry denied it had made any such order (CBC News 2017). The crucifix was, however, accompanied by a plaque that reads as follows:

In the years following the First World War, the only hospital, L'Hôtel-Dieu in Québec City, was no longer sufficient for the demand. A new hospital was needed. Dr. Arthur Rousseau wanted an establishment for both private patients and poor patients. He obtained the support of the government and the archdiocese and founded a large general hospital equipped with all the modern services needed to treat the sick as well as a school to train future doctors.

Indeed, l'Hôpital du Saint-Sacrement was first conceived to be a university hospital and this was its vocation. It was the nuns of l'Hôtel-Dieu de Québec who took charge of it, and then were succeeded in June 1927 by les Soeurs de la Charité de Québec. Seven departments, governed by eminent physicians, were officially inaugurated on 15 December 1927.

Health care institutions in Québec have been secular for many years. This crucifix recalls the importance of the contribution of religious communities to the construction of this hospital. (Radio-Canada 2017)

What does this incident tell us about religion in the public sphere in Canada? The context is important: first, the removal occurred in the wake of the Supreme Court of Canada's Saguenay decision, which involved a challenge by an atheist to the recitation of prayer and the presence of a crucifix in a municipal council. The Court held that "[i]f the state adheres to a form of religious expression under the guise of cultural or historical reality or heritage, it breaches its duty of neutrality" (Saguenay at para. 78). Though the Saguenay case occurred in Québec, the Court's decision prompted a public outcry that revealed the extent to which prayer is still a part of municipal government proceedings throughout Canada. Specifically, it turned out that many municipal councils and legislative bodies were still saying Christian prayers at the beginning of their public meetings. Some of them vowed

religieux, tel qu'une croix accrochée au mur, peut revêtir un caractère contraignant incompatible avec les droits et libertés de la personne."

19 Christine L. Cusack and I examined some 40 documents-newspaper articles, blogs, press releases and website statements-to analyze the public discourse about the Saint-Sacrement incident. 
to continue to do so, even in the face of the decision of the Court that this was not in keeping with a neutral state. Despite the promise of multiculturalism, Christianity as the majoritarian religion still retains a position of privilege, albeit now under the guise of heritage and culture. The second contextualizing factor is that there have been a series of attempts to introduce legislation in Québec that would regulate the wearing of religious symbols in the public sphere. Bill 94 was introduced in March $2010^{20}$, Bill 60 in November $2013^{21}$, and Bill $62^{22}$ in 2015. These bills have been much discussed within the framework of reasonable accommodation. The Saint-Sacrement incident illustrates the inscription of the 'Us' who is accommodating-'We' have culture and heritage, others have religion. One comment in the media stated,

\section{For better or for worse, in our world religious identities are resurging. Reminding of the importance of the crucifix, in these circumstances, is to remind immigrants that they are here in the Occident, and that Christianity is not one religion among others. It is that which formed our civilization. Everyone must accept this. ${ }^{23}$}

This statement captures a number of the features of public discussions around religion: that religion is resurging; that it is specifically immigrants from the 'Orient' who need to be reminded of Christianity's place of privilege; that it is Christianity that is the founding religion; and that new religious diversity is not characterized by equality or multiculturalism, but a hierarchical configuration that preserves existing power relationships. These types of statements were pervasive during the discussions about Saint-Sacrement and originated from public officials, groups and individuals. ${ }^{24}$ On 18 October 2017, Québec's Bill 62 became law, with the provincial government insisting on questions of "communication identification, or security" as primary rationales for the new restrictions on face-coverings (Shingler 2017).

Nonetheless, the new diversity is reshaping power relations vis-à-vis established religion, ${ }^{25}$ sometimes using legal mechanisms such as human rights guarantees to challenge the status quo. The crucifix at Saint-Sacrement was reinstated, but with an accompanying descriptor that contextualizes its presence. In the Saguenay decision the Supreme Court of Canada recognized the potential for 'culture and heritage' to be misused to preserve privilege. Nonreligion and minority religion are the two catalysts for this shift. Contests over religion in the public sphere are not necessarily aimed at the removal or elimination of majoritarian practices and symbols, but a reconfiguration of presence.

20 Bill 94, which was introduced by the Liberal government, was entitled "An Act to establish guidelines governing accommodation requests within the Administration and certain institutions." This bill called for the ban on the wearing of the niqab and emphasized "un visage découvert" or "naked face" when public service was provided or received in Québec. See Fournier and See (2014) for their argument that the bill effectively extended the public sphere and disproportionately impacted Muslim women.

21 The full title of Bill 60, introduced by the Parti Québecois government, was the "Charter affirming the values of State secularism and religious neutrality and of equality between women and men, and providing a framework for accommodation requests." This bill proposed to ban civil servants from wearing religious symbols—turbans, kippas, head scarves, burkas, and large crosses-while at work. For a critical analysis of the so-called "Charter of Values" see The Immanent Frame (2014).

22 Bill 62, introduced by the Liberal government in 2015, is known as "An Act to foster adherence to State religious neutrality and, in particular, to provide a framework for religious accommodation requests in certain bodies." It is this Bill that the hospital board of Saint-Sacrement referred to in discussing its need to effect policies that are in keeping with state neutrality. The bill became law on 18 October 2017 effectively banning the wearing of the niqab by public servants, those who use government services, and in citizenship ceremonies.

23 Translated by Christine L. Cusack. (Bock-Côté 2017).

24 There were counter-statements that supported the actions of the Saint-Sacrement hospital board and did not take up the culture and history rhetoric, but they were less frequent than those that positioned the crucifix as a foundational part of culture and heritage. Not all were as blunt as the statement cited, but were variations on this theme. This research is based on content analysis of selected media reports about the removal and reinstatement of a crucifix at the Saint Sacrement Hospital in Quebec City. Specifically, newspaper articles from 22 February to 14 March 2017 were gathered from the databases Pro-Quest Canadian Major Dailies and Factiva.

25 Winnifred Sullivan and I have argued that formal legal arrangements aside, de facto religious establishment exists in every country: "Establishment focuses us on the background cultural assumptions, cosmologies, anthropologies and institutions used to manage religion, as well as both internal and external religious diversity; it is historically and culturally specific, and reveals difficulties with universal multicultural and interfaith models" (Beaman and Sullivan 2013, p. 8). 
That may take the shape of a moment of silence instead of prayer, or explanatory information that acknowledges the contribution of particular religious groups to social goods such as healthcare. It means a shift in institutional practices and frameworks for responding to difference.

\subsection{Zunera Ishaq}

On 9 October 2015, 29-year-old Zunera Ishaq took the oath of citizenship and became a Canadian citizen. Wearing a beautiful floral niqab, Ishaq's eyes expressed delight. Her sartorial presentation is relevant because she fought a year-long battle through the courts for the right to wear her niqab while taking the oath. Her case generated considerable public discussion. ${ }^{26}$ The then Conservative Prime Minister made a number of public statements regarding the case, saying "it is offensive that someone would hide their identity at the very moment where they are committing to join the Canadian family" (Whittington and Keung 2015). The Conservative Party's website dedicated a webpage to the niqab saying covering one's face while being sworn in is "not the way we do things here" (Conservative Party of Canada 2015). The then Prime Minister also called the niqab a "product of a culture that is anti-woman."(Chase 2015) In addition, he made a statement in which he divided 'new' and 'old stock' Canadians (CBC News 2015). During the federal election campaign a 'Barbaric Cultural Practices' hotline was promised if the Conservatives were re-elected (Powers 2015). The Federal Court of Appeal, which had the final word on the matter, upheld Ishaq's right to wear the niqab, stating that "there is no evidence of broad effects upon Muslim women generally or the larger Muslim community" (Ishaq FCA at para. 36). The Federal Court of Appeal dismissed the government's motion to stay the matter pending appeal to the Supreme Court of Canada.

The government had suggested that Ishaq could sit in the front or back row at the ceremony (next to a woman) so that when she removed her face covering, no one could see. This was described as an 'accommodation', and when Ishaq rejected this proposal she was essentially told that citizenship is a privilege, not a right and that "she should just accept the consequences of not becoming a citizen; she will still retain all the benefits of permanent residence" (Ishaq at para. 39). Ishaq reiterated that citizenship was important to her and that denying her citizenship as long as she was wearing the niqab made her "feel worthless and as if she does not belong in the Canadian family" (Ishaq at para. 27). Ishaq was essentially identifying a lack of meaningful inclusion and equality. The case illustrates the problem with accommodation: the take it or leave it approach of the party offering the accommodation (in this case the federal government) exposed the hierarchical structure that is inherent in that model. ${ }^{27}$

Multiculturalism was also part of the conversation in the Ishaq case. Ishaq invoked the Multiculturalism Act in her aid, pointing to the sections that require federal officials to "(c) promote policies, programs and practices that enhance the understanding of and respect for the diversity of the members of Canadian society;... (f) generally, carry on their activities in a manner that is sensitive and responsive to the multicultural reality of Canada" (Ishaq at para. 63). The provisions drawn upon by Ishaq were in fact incorporated into the citizenship manual, which states: "Any comments made and actions taken at a citizenship ceremony must respect and promote a better understanding and appreciation of Canada's diverse cultures" (Ishaq at para. 64). Both the Federal Court and the Federal Court of Appeal found in Zunera Ishaq's favour; however, the Federal Court noted that

26 Ishaq v Canada (Citizenship and Immigration), [2015] 4 FCR 297, 2015 FC 156 [Ishaq] aff'd in Canada (Citizenship and Immigration) v Ishaq, [2016] 1 FCR 686, 2015 FCA 151 [Ishaq FCA]. See also Beaman 2016.

27 This was further reinforced by the following statement in the decision of the Federal Court: "Similarly, in response to some queries about potential accommodations, another CIC official wrote in an email dated 13 December 2011, that: Under the new directive [Operational Bulletin 359] ... all candidates for citizenship must be seen taking the oath of citizenship at a citizenship ceremony. For candidates wearing full or partial face coverings, face coverings must be removed at the oath taking portion of the ceremony in order for CIC officials and the presiding official (Citizenship Judge) to ensure that the candidate has in fact taken the Oath of Citizenship. Under this new directive there are no options for private oath taking or oath taking with a female official as all candidates for citizenship are to repeat the oath together with the presiding official. [Emphasis added]" (Ishaq at para. 47). 
"the Minister did not consider allowing women to wear niqabs while taking the oath of citizenship to be an appropriate way to implement multiculturalism policy and, in my view, that does not infringe the [Canadian Multiculturalism Act]" (Ishaq at para. 65). Given that the court ruled in Ishaq's favour we might infer that the court disagreed with the Minister's interpretation of what it means to implement multiculturalism.

What does the Ishaq case tell us about diversity and religion in the public sphere in Canada? While there are multiple narratives about diversity in Canada, here we see a model of inclusion which integrates a robust conceptualization of equality. The court displaced the argument that it was necessary to actually see Ishaq taking the oath by drawing on other possible scenarios: "any requirement that a candidate for citizenship actually be seen taking the oath would make it impossible not just for a niqab-wearing woman to obtain citizenship, but also for a mute person or a silent monk" (Ishaq at para. 61). The accommodation-based arguments of the federal government failed, and instead an equality-based version of multiculturalism prevailed.

\subsection{The Peel Region}

The Regional Municipality of Peel, located in southern Ontario, is home to two English language school districts: the Peel District School Board and the Dufferin-Peel Catholic District School Board. ${ }^{28}$ Over the past five years, a number of controversies have erupted in this region, suggesting that it is a cauldron of tensions around the new diversity in which majoritarian religion, minority religions, and nonreligion are being worked out. The Peel Region does not have any particularly unique characteristics that make it more likely to be a site for such conflict, but it is an interesting microcosm of the intersections of diversities. It is a regional municipality made up of 1.3 million people, $50 \%$ of which identify as visible minorities ${ }^{29}$ (a higher percentage than other areas according to its 'Diversity and Inclusion Strategy' (Region of Peel 2010) and so is highly diverse.

In 2013 Oliver Erazo, whose two children attended Notre Dame Catholic Secondary School, sought the help of the Ontario Superior Court. ${ }^{30}$ Erazo had chosen the Catholic school, despite the fact that neither he nor his children were Catholic, because the school had a reputation for being the best in the district. Despite this, until grade 9, his children had attended religious programmes and classes in the school. But, as time progressed his children's interests expanded and they wished to take other classes in lieu of the religious instruction and religious programmes. An exemption from these activities was well within the Education Act, but a question arose as to what constituted a programme. While Erazo had no objection to the religious and moral education that was part of the school curriculum (including prayer at the beginning of the day and religious content that infused various classes), he did object to religious retreats and mandatory attendance at mass. With no resolution at the local level, Erazo turned to the law. The court held that the children should be exempted from retreats and Catholic mass, and that the purpose of the exemption section in the legislation was to "give relief to students who may respect many Catholic principles and observances but do not wish to participate in Catholic, or perhaps any, form of worship, even at a minimal level of participation. For some of them, that might well require a betrayal of their own principles. No Catholic school system that is required by law to admit non-Catholic students should have the right to require such participation from their students" (Erazo at para. 27). ${ }^{31}$

28 The district is publicly funded. The issues might shift if the religious schools were private, but that issue is beyond the scope of this article.

29 Data from the 2011 Census National Household Survey specific to newcomers in the Peel Region show that South Asians (56.51\%) represent the highest population group of visible minorities, followed by Filipinos $(10.02 \%)$ and Blacks $(9.61 \%)$ (Region of Peel 2017). Newcomer Top 3 Visible Minority Groups. Peel Data Centre. Available online: https://www. peelregion.ca/planning-maps/newcomers/ (Region of Peel 2017).

30 Erazo v Dufferin-Peel Catholic District School Board, 2014 ONSC 2072 [Erazo].

31 In an adjoining district, a similar human rights case arose when a student claimed that her request to be exempted from confessional religious courses resulted in discrimination and prohibitions from attending other school events. While this 
A second incident illuminates another facet of tensions around religion: in September 2016, the Peel District School Board changed a policy that had been in place for twenty years allowing Muslim students to hold independent, twenty minute Friday prayer sessions in an empty classroom space. Students were no longer able to recite prayers that they had written (which would then get approved by school staff) -instead, students were restricted to reciting six pre-approved sermons. Sermons were to be spoken in English (except for Quranic verses) under the supervision of a staff member. Following outcry by parents and students, the school board reverted to its original policy in January 2017 (Murphy 2017). Debate then arose regarding whether the students should even be allowed to pray on school grounds, with a group called Religion out of Public Schools starting a petition calling for an end to the prayer space practice. Protests erupted at school board meetings, and included an incident of an attendee tearing up a Quran and others yelling Islamophobic comments (McGillivray 2017).

This conflict was rooted not only in tensions between the religious and nonreligious, but also between religious minorities. One media source noted that the majority of protestors were South Asian, and that one such protestor (who refused to be labeled as a Hindu but as "Canadian" instead) carried a sign declaring "There is no such thing as 'religious accommodation' in the Ontario Human Rights Code." According to this source, the debate surrounding the prayer "has awakened old tensions in the South Asian community" stemming from British India's partition into a "predominantly Hindu India and predominantly Muslim Pakistan." (Bascaramurty and Alphonso 2017) As another media report noted, "Critics argue a secular school system should not accommodate religion. But Ontario boards, both public and Catholic, are legally required to provide religious accommodation when it is requested." (Alphonso 2017)

The Peel District School Board now includes a "Religious Accommodation: Key Facts" document on their website. Stated at the end of the fact sheet:

\begin{abstract}
It has been frustrating and disheartening to see what is often hatred and prejudice towards a single faith group disguised in a supposed campaign about religion in schools. No one has expressed concern about school-wide celebration of Diwali, or that we provide vegetarian options in food, or post posters acknowledging all major faith days, including Christmas. This is a campaign against Islam-counter to the laws of the Country, the Ontario Human Rights Code, and our board values. (Peel District School Board 2017)
\end{abstract}

These two incidents involved nonreligious, majoritarian religion, and minority religions contesting the place of religion in public spaces, in publicly funded schools. The language of accommodation, which we see in the Peel District School Board's policy and statement as well as in the media discussion circulates to frame the conversation. However, in the 'Key Facts' document cited above the content of the statement evidences a sophisticated understanding of equality as well as a pointed naming of the events as hatred, prejudice, and anti-Muslim. The document might well be named 'religious inclusion' instead of 'religious accommodation.' The Board's recommended procedures for providing religious accommodations also includes nonreligion: "The Board respects the practice of diverse religious traditions within the system and individuals or groups who do not belong to an organized religion or practice a religion" (Peel District School Board 2017, p. 2). The Board sets an inclusive tone, highlighting respect as a cornerstone of social relations in the schools, facilitating what I have described elsewhere as deep equality (see Beaman 2017). The legal requirement for accommodation mentioned in the media report shifts the conversation to law and whether it requires accommodation. Yet, in its own policy and deliberations the school board combines a legal requirement with values to produce an inclusive vision. A religion free school is not part of that vision, something the Board makes 
clear. So too does Oliver Erazo leave space for religion. Though we might argue that his children are attending a Catholic school, the reality is that many parents choose Catholic schools in the Ontario system because they are perceived to offer a better quality of education. Erazo had no objection to daily prayers or the integration of religion in his children's classes, but wanted to expand their options for other facets of their education.

\section{Conclusions}

In this context of new diversity in Canada religion in the public sphere is contested territory. The examples above illustrate some of the contours of that territory. Not all cases (a minority in fact) come before the law, but legal cases leave more enduring records of the contests and the arguments. The cases contain traces of some of the defining narratives of Canadian identity more broadly. Multiculturalism, for example, is deployed legalistically, but also as an ethic of inclusion. It is thus mobilized by individuals, groups, and social institutions such as education (though there we see diversity, respect, and inclusion as placeholders for multiculturalism) to restructure power relations and displace majoritarian privilege. The language of accommodation subverts equality, but, as we see in the Peel example, can itself be reshaped to challenge obstacles to equality. The requirement for accommodation in that example is used as a launching place for countering prejudice, albeit in partnership with values mobilized in the name of the school board.

Moving forward, and based on the cases surveyed here, what might we anticipate responses to the new diversity to look like in Canada? As can be seen, the range of responses is wide and cannot be reduced to a simplistic analysis or set of rules. We might, for example, argue that the Ishaq case is decided the way it is because it pertains to one individual. But each situation can be marshalled to be representative of broader battles, issues, or values (as was the case in Ishaq). Prediction is a dangerous undertaking, but there seems to be a genuine commitment to rethinking a status quo that would privilege majoritarian religion and there is reason to hope that this is the direction of the future. The results are not always conducive to inclusion or responsive to the imperatives presented by the new diversity, but each of the cases evidences a shift toward a rethinking of past practices to create space for a more inclusive future.

As the nones become an increasingly significant proportion of the population the extent to which majoritarian religion shapes public institutions is increasingly exposed. In an editorial posted in the Globe and Mail objecting to the simultaneous construction of two new government-funded public and Catholic schools in Toronto, Marcus Gee wrote

\section{Residents from all sorts of backgrounds are thrown together in one community. Why, then, is it getting two different schools? What is the rationale, in a multicultural city that is striving to integrate throngs of newcomers, for maintaining and funding a whole separate school system established on religious grounds? ... Toronto is not a city of churches, divided between dominant Protestants and minority Catholics. It is a city of the world. Its residents come from every part of the planet and practice every known religion, from Islam to Tibetan Buddhism to Zoroastrianism. Many have no religion at all. It is a much more secular age. ${ }^{32}$}

Although the concept of the secular has limited use and is itself highly contested, Gee's editorial comments illustrate the questions that are emerging in this rapidly shifting (non)religious landscape. Recognizing the demographic reality of multiculturalism, the statement pushes further to challenge the historic privilege granted to one religion and calls for different power relations. Set in a global context, the call is for a reshaping of state and institutional responses to the new diversity.

32 Gee 2017. Toronto Needs a Singular, Secular School System. The Globe and Mail. Available online: https:/ /beta.theglobeandmail. com/news/toronto/toronto-needs-a-single-secular-school-system/article35264933/?ref=http:/ /www.theglobeandmail.com\& (accessed on 3 October 2017). 
Acknowledgments: I would like to acknowledge the support of the Religion and Diversity Project in the preparation of this article as well as the ongoing financial support of my research through my Canada Research Chair in Religious Diversity and Social Change. I am also grateful to Marianne Abou-Hamad for her research and editorial assistance, to Christine L. Cusack for her research assistance, and to Keelin Pringnitz for her research assistance on multiculturalism.

Conflicts of Interest: The author declares no conflict of interest.

\section{References}

Adams, Michael. 2007. Unlikely Utopia: The Surprising Triumph of Multiculturalism. Toronto: Penguin.

Alidadi, Katayoun. 2012. Reasonable Accommodations for Religion and Belief: Adding Value to Article 9 ECHR and the European Union's Anti-Discrimination Approach to Employment? European Law Review 37: 693-715.

Alphonso, Caroline. 2017. Ontario School Board's Muslim Support Fuels Hate, Threats. Globe and Mail, April 18. Available online: https:/ / beta.theglobeandmail.com/news/toronto/peel-school-boards-muslim-supportfuels-hate/article34746614/ ?ref=http:/ / www.theglobeandmail.com\& (accessed on 3 October 2017).

Australian Bureau of Statistics. 2013. Table B14: Religious Affiliation by Sex. Available online: http://stat.abs.gov. au/Index.aspx?DataSetCode=ABS_CENSUS2011_B14 (accessed on 26 September 2017).

Himani Bannerji, ed. 2001. The Dark Side of the Nation: Essays on Multiculturalism, Nationalism and Gender. Toronto: Canadian Scholars' Press.

Barras, Amélie. 2016. Exploring the Intricacies and Dissonances of Religious Governance: The Case of Québec and the Discourse of Request. Critical Research on Religion 4: 57-71. [CrossRef]

Bascaramurty, Dakshana, and Caroline Alphonso. 2017. A Community Divided. Globe and Mail, April 28. Available online: https:/ / beta.theglobeandmail.com/news/toronto/a-community-divided-the-fight-over-canadianvalues-threatens-to-boil-over-inpeel/article34852452/?ref=http:/ / www.theglobeandmail.com\& (accessed on 3 October 2017).

Beckford, James. 2003. Social Theory and Religion. Cambridge: Cambridge University Press.

Beckford, James A. 2014. Re-thinking Religious Pluralism. In Religious Pluralism: Framing Religious Diversity in the Contemporary World. Edited by Giuseppe Giordan and Enzo Pace. Heidelberg: Springer, pp. 15-29.

Beaman, Lori G. 2011. 'It was all slightly unreal': What's Wrong with Tolerance and Accommodation in the Adjudication of Religious Freedom? Canadian Journal of Women and Law 23: 442-63. [CrossRef]

Beaman, Lori G. 2012. The Missing Link: Tolerance, Accommodation and ... Equality. Canadian Diversity 9: 16-9.

Beaman, Lori G. 2013. Tolerance and Accommodation as Vestiges of the Empire. In Secular States and Religious Diversity. Edited by Bruce Berman, Rajeev Bhargava and André Laliberté. Vancouver: UBC Press, pp. 120-35.

Beaman, Lori G., and Winnifred F. Sullivan. 2013. Neighbo(u)rly Misreadings and Misconstruals: A Cross-Border Conversation. In Varieties of Religious Establishment. Edited by Winnifred F. Sullivan and Lori G. Beaman. Farnham: Ashgate, pp. 1-11.

Beaman, Lori G. 2014. Deep Equality as an Alternative to Accommodation and Tolerance. Nordic Journal of Religion and Society 27: 89-111.

Beaman, Lori G. 2016. Living Together v. Living Well Together: A Normative Examination of the SAS Case. Social Inclusion 4: 3-13. [CrossRef]

Beaman, Lori G. 2017. Deep Equality in an Era of Religious Diversity. Oxford: Oxford University Press.

Beyer, Peter. 2013. Islam, Hinduism, and Buddhism: Differential Reconstruction of Religions. In Growing up Canadian: Muslims, Hindus, Buddhists. Edited by Peter Beyer and Rubina Ramji. Montreal: McGill-Queen's University Press, pp. 53-73.

Peter Beyer, and Rubina Ramji, eds. 2013. Growing Up Canadian: Muslims, Hindus, Buddhists. Montreal: McGill-Queen's University Press.

Beyer, Peter, Alyshea Cummins, and Scott Craig. 2016. Measuring Religious Identity Differently: A Canadian Survey Study. Bulletin for the Study of Religion 45: 10-5. [CrossRef]

Block, Tina. 2017. The Secular Northwest: Religion and Irreligion in Everyday Postwar Life. Vancouver: University of British Columbia Press.

Bock-Côté, Mathieu. 2017. Pourquoi le crucifix passionne-t-il autant? Le Journal de Montréal, March 1. Available online: http:/ / www.journaldemontreal.com/2017/03/01/pourquoi-le-crucifix-passionne-t-il-autant (accessed on 2 October 2017). 
Bouchard, Gérard, and Charles Taylor. 2008. Building the Future: A Time for Reconciliation. Quebec City: Commission de Consultation sur les Pratiques d'Accommodement Reliées aux Différences Culturelles.

Bouchard, Gérard. 2011. What is Interculturalism? McGill Law Journal 56: 435-68.

Bramadat, Paul. 2008. Religion and Public Policy in Canada: An Itinerary. Studies in Religion 37: 121-43. [CrossRef] Bramadat, Paul, and David Seljak. 2008. Conclusion: The Discourse of Loss and the Future of Christianity and Ethnicity in Canada. In Christianity and Ethnicity in Canada. Toronto: University of Toronto Press, pp. 415-35.

Bribosia, Emmanuelle, Julie Ringelheim, and Isabelle Rorive. 2009. Aménager la diversité: le droit de l'égalité face à la pluralité religieuse. Brussels: Revue trimestrielle des droits de l'homme, pp. 319-73.

Bribosia, Emmanuelle, Julie Ringelheim, and Isabelle Rorive. 2010. Reasonable Accommodation for Religious Minorities: A Promising Concept for European Antidiscrimination Law? Maastricht Journal of European and Comparative Law 17: 137-61. [CrossRef]

Bribosia, Emmanuelle, Andrea Rea, Julie Ringelheim, and Isabelle Rorive. 2011. Reasonable Accommodation of Religious Diversity in Europe and in Belgium. Law and Practice. In The Others in Europe: Legal and Social Categorization in Context. Edited by Andrea Rea, Saskia Bonjour and Dirk Jacobs. Brussels: PUB, pp. 91-116.

CBC News. 2015. Stephen Harper Explains ‘Old-Stock Canadians' Comment. Available online: http:/ /www.cbc. $\mathrm{ca} /$ news / politics / canada-election-2015-harper-debate-1.3233785 (accessed on 2 October 2017).

CBC News. 2017. Québec City Hospital to Once Again Display Controversial Crucifix. Available online: http: / / www.cbc.ca/news/canada/montreal/Québec-city-hospital-threat-crucifix-arrest-1.4004482 (accessed on 29 September 2017).

Chase, Steven. 2015. Niqabs 'Rooted in a Culture That Is Anti-Women,' Harper Says. Globe and Mail. March 10. Available online: https:/ / beta.theglobeandmail.com/news/politics/niqabs-rooted-in-a-culture-that-is-antiwomen-harper-says/article23395242/?ref=http:/ / www.theglobeandmail.com\& (accessed on 2 October 2017).

Choudhry, Sujit. 2013. Rights Adjudication in a Plurinational State: The Supreme Court of Canada, Freedom of Religion, and the Politics of Reasonable Accommodation. Osgoode Hall Law Journal 50: 575-608.

Connolly, William E. 2005. Pluralism. Durham: Duke University Press. Durham: Duke University Press.

Conservative Party of Canada. 2015. Not the Way We Do Things Here. Ottawa: Conservative Party of Canada.

Crul, Maurice. 2015. Super-diversity vs. Assimilation: How Complex Diversity in Majority-minority Cities Challenges the Assumptions of Assimilation. Journal of Ethnic and Migration Studies 42: 54-68. [CrossRef]

Day, Richard J.F. 2000. Multiculturalism and the History of Canadian Diversity. Toronto: University of Toronto Press.

Day, Shelagh, and Gwen Brodsky. 1996. The Duty to Accommodate: Who Will Benefit? Canadian Bar Review 75: 433-73.

De Bock, Jozefien. 2014. Not All the Same after All? Superdiversity as a Lens for the Study of Past Migrations. Ethnic and Racial Studies 38: 583-95. [CrossRef]

Dewing, Michael. 2013. Canadian Multiculturalism. Available online: https://lop.parl.ca/content/lop/ ResearchPublications / 2009-20-e.pdf (accessed on 2 October 2017).

Fokas, Effie. 2015. Directions in Religious Pluralism in Europe: Mobilisations in the Shadow of European Court of Human Rights Religious Freedom Jurisprudence. Oxford Journal of Law and Religion 4: 54-74. [CrossRef]

Fournier, Pascale, and Erica See. 2014. The 'Naked Face' of Secular Exclusion: Bill 94 and the Privatization of Belief. In Religion in the Public Sphere: Canadian Case Studies. Edited by Solange Lefebvre and Lori G. Beaman. Toronto: University of Toronto Press, pp. 275-93.

Furseth, Inger. 2017. Religious Complexity in the Public Sphere: Comparing Nordic Countries. London: Palgrave Macmillan.

Gee, Marcus. 2017. Toronto Needs a Singular, Secular School System. Globe and Mail, June 9. Available online: https: / beta.theglobeandmail.com/news / toronto/toronto-needs-a-single-secular-school-system/ article35264933/?ref=http:/ / www.theglobeandmail.com\& (accessed on 3 October 2017).

Gibson, Matthew. 2013. The God 'Dilution'? Religion, Discrimination and the Case for Reasonable Accommodation. The Cambridge Law Journal 72: 578-616. [CrossRef]

Habermas, Jürgen. 1996. Between Facts and Norms: Contributions to a Discourse Theory of Law and Democracy. Translated by William Rehg. Cambridge: The MIT Press.

Habermas, Jürgen. 2006. Religion in the Public Sphere. European Journal of Philosophy 14: 1-25. [CrossRef]

Hamilton, Graeme. 2017. After Outcry, Québec Hospital Restores Crucifix Taken down in Interest of 'Religious Neutrality'. National Post. March 1. Available online: http://nationalpost.com/news/canada/ after-outcry-Québec-hospital-restores-crucifix-taken-down-in-interest-of-religious-neutrality (accessed on 29 September 2017). 
Hansen, Randall. 2017. Why Both the Left and the Right Are Wrong: Immigration and Multiculturalism in Canada. Political Symposium 50: 712-16. [CrossRef]

Kernerman, Gerald P. 2005. Multicultural Nationalism: Civilizing Difference, Constituting Community. Vancouver: University of British Colombia Press.

Kymlicka, Will. 1995. Multicultural Citizenship: A Liberal Theory of Minority Rights. Oxford: Oxford University Press. Kymlicka, Will. 2005. Multicultural Odysseys: Navigating the New International Politics of Diversity. Oxford: Oxford University Press.

Kymlicka, Will. 2011. Multicultural Citizenship within Multination States. Ethnicities 11: 281-302. [CrossRef]

James, William Closson. 2012. Dimorphs and Cobblers: Ways of Being Religious in Canada. In Religion and Canadian Society: Contexts, Identities, and Strategies, 2nd ed. Edited by Lori G. Beaman. Toronto: Canadian Scholars' Press, pp. 55-68.

Jolls, Christine. 2001. Antidiscrimination and Accommodation. Harvard Law Review 115: 643-99. [CrossRef]

Laborde, Cécile. 2009. Républicanisme critique vs républicanisme conservateur: Repenser les 'accommodements raisonnables'. Critique Internationale 44: 19-33. [CrossRef]

Levin, Brian, James J. Nolan, and Barbara Perry. 2015. Disrupting the Mantra of Multiculturalism. American Behavioral Scientist 59: 1637-54.

Markell, Patchen. 2003. Bound by Recognition. Princeton: Princeton University Press.

Marks, Lynn. 2017. Infidels and the Damn Churches: Irreligion and Religion in Settler British Columbia. Vancouver: University of British Columbia Press.

Martínez-Torrón, Javier. 2014. Religious Pluralism: The Case of the European Court of Human Rights. In Democracy, Law and Religious Pluralism in Europe Secularism and Post-Secularism. Edited by Ferran Requejo and Camil Ungureanu. New York: Routledge, pp. 123-46.

McQuigge, Michelle. 2017. Students Can Opt Out of Religious Classes at Ontario Catholic School after Complaint Settled. Available online: https:/ /globalnews.ca/news/3523369/students-can-opt-out-of-religious-classesat-ontario-catholic-school-after-complaint-settled/ (accessed on 3 October 2017).

Meissner, Fran, and Steven Vertovec. 2015. Comparing Super-diversity. Ethnic and Racial Studies 38: 541-55. [CrossRef]

Meissner, Fran. 2016. Socialising with Diversity: Relational Diversity through a Superdiversity Lens. London: Palgrave Macmillan.

Modood, Tariq. 2005. Multicultural Politics: Racism, Ethnicity, and Muslims in Britain. Minneapolis: University of Minnesota Press.

Mudde, Cas. 2016. Putting Canada in a Comparative Context: Still the Multiculturalist Unicorn. Nationalism and Ethnic Politics 22: 351-57. [CrossRef]

Murphy, Jessica. 2017. Toronto-Area Peel District School Board in Muslim Prayer Row. Available online: http: / /www.bbc.com/news/world-us-canada-39508319 (accessed on 26 September 2017).

Nayar, Kamala. 2012. The Punjabis in British Columbia: Location, Labour, First Nations, and Multiculturalism. Montreal: McGill-Queen's University Press.

Ng, Eddy S, and Irene Bloemraad. 2015. A SWOT Analysis of Multiculturalism in Canada, Europe, Mauritius, and South Korea. American Behavioral Scientist 59: 619-36. [CrossRef]

Padilla, Beatriz, Joana Azevedo, and Antonia Olmos-Alcaraz. 2015. Superdiversity and Conviviality: Exploring Frameworks for Doing Ethnography in Southern European Intercultural Cities. Ethnic and Racial Studies 38: 621-35. [CrossRef]

Peel District School Board. 2017. Religious Accommodation. Available online: http://www.peelschools.org/ trustees/boardpolicies / Documents/FINAL\%20Religious\%20Accommodation\%20COMS8.pdf\#search= religious\%20accommodation\%20policy (accessed on 3 October 2017).

Pew Forum on Religion and Public Life. 2012a. "Nones" on the Rise. Available online: http: / www.pewforum. org/2012/10/09/nones-on-the-rise/ (accessed on 26 September 2017).

Pew Forum on Religion and Public Life. 2012b. The Global Religious Landscape. Available online: http: / / www.pewforum.org/2012/12/18/global-religious-landscape-exec/ (accessed on 26 September 2017).

Pew Forum on Religion and Public Life. 2013. Canada's Changing Religious Landscape. Available online: http: / / www.pewforum.org/2013/06/27/ canadas-changing-religious-landscape/ (accessed on 2 October 2017). 
Powers, Lucas. 2015. Conservatives pledge funds, tip line to combat 'barbaric cultural practices'. CBC News, October 2. Available online: http:/ / www.cbc.ca/news/politics/canada-election-2015-barbaric-culturalpractices-law-1.3254118 (accessed on 2 October 2017).

Johannes Quack, and Cora Schuh, eds. 2017. Religious Indifference: New Perspectives from Studies on Secularization and Nonreligion. Cham: Springer.

Radio-Canada. 2017. Le crucifix de retour à l'hôpital du Saint-Sacrement. Available online: http:/ /ici.radio-canada. ca/nouvelle/1019915/crucifix-reinstalle-hopital-du-saint-sacrement-Québec-controverse (accessed on 29 September 2017).

Region of Peel. 2010. Diversity and Inclusion Strategy. Available online: https:/ /www.peelregion.ca/corpserv / diversity10/SIP.pdf (accessed on 3 October 2017).

Region of Peel. 2017. Newcomer Top 3 Visible Minority Groups. Available online: https:/ /www.peelregion.ca/ planning-maps/newcomers/ (accessed on 3 October 2017).

Ryan, Phil. 2010. Multicultiphobia. Toronto: University of Toronto Press.

Ryan, Phil. 2016. Does Canadian Multiculturalism Survive Through State Repression? Nationalism and Ethnic Politics 22: 342-50. [CrossRef]

Sheppard, Colleen. 2010. Inclusive Equality: The Relational Dimensions of Systemic Discrimination in Canada. Montreal: McGill Queen's University Press.

Shingler, Benjamin. 2017. Amid Criticism, Quebec Explains the Rules of its Face-covering Ban. CBC News Montreal. Available online: http:/ / www.cbc.ca/news/canada/montreal/quebec-face-covering-guidelinesbill-62-1.4368594 (accessed on 14 November 2017).

Statistics Canada. 2001. Table: Major Religious Denominations, Canada, 1991 and 2001. Available online: http: / / www12.statcan.gc.ca/english/census01/Products/Analytic/companion/rel/tables/canada/ cdamajor.cfm\#ftnt1 (accessed on 26 September 2017).

Statistics Canada. 2011. NHS Profile, Canada, 2011. Available online: http://www12.statcan.gc.ca/nhs$\mathrm{enm} / 2011 / \mathrm{dp}-\mathrm{pd} /$ prof/details / page.cfm?Lang=E\&Geo1=PR\&Code1=01\&Data=Count\&SearchText=01\& SearchType=Begins \&SearchPR=01\&A1=All\&B1=All\&Custom $=\& T A B I D=3$ (accessed on 26 September 2017).

Statistics Canada. 2013a. 2011 National Household Survey: Immigration, Place of Birth, Citizenship, Ethnic Origin, Visible Minorities, Language and Religion. Available online: http:/ / www.statcan.gc.ca/daily-quotidien/ 130508/dq130508b-eng.htm (accessed on 26 September 2017).

Statistics Canada. 2013b. Immigration and Ethnocultural Diversity in Canada. Available online: http:/ /www12. statcan.gc.ca/nhs-enm/2011/as-sa/99-010-x/99-010-x2011001-eng.pdf (accessed on 2 October 2017).

Statistics Canada. 2016. 150 years of Immigration in Canada. Available online: http:/ /www.statcan.gc.ca/pub/ 11-630-x/11-630-x2016006-eng.htm\#def2 (accessed on 29 September 2017).

Statistics Canada. 2017. Immigration and Ethnocultural Diversity: Key Results from the 2016 Census. Available online: http:/ / www.statcan.gc.ca/daily-quotidien/171025/dq171025b-eng.htm (accessed on 14 November 2017).

Thiessen, Joel. 2015. The Meaning of Sunday: The Practice of Belief in a Secular Age. Montreal: McGill-Queens University Press.

The Immanent Frame. 2014. The Charter of Québec Values: Off the Cuff. Available online: http:/ /blogs.ssrc.org/ tif/2014/02/20/the-charter-of-Québec-values (accessed on 29 September 2017).

Thurairajah, Kalyani. 2017. The Jagged Edges of Multiculturalism in Canada and the Suspect Canadian. Journal of Multicultural Discourses 12: 134-48. [CrossRef]

Tomlins, Steven. 2010. In Science We Trust: Dissecting the Chimera of New Atheism. Master's thesis, University of Ottawa, Ottawa, ON, Canada.

Tomlins, Steven. 2015. A Common Godlessness: A Snapshot of a Canadian University Atheist Club, Why Its Members Joined, and What That Community Means to Them. In Atheist Identities: Spaces and Social Contexts. Edited by Lori G. Beaman and Steven Tomlins. Cham: Springer, pp. 117-36.

Vertovec, Steven. 2007. Super-diversity and Its Implications. Ethnic and Racial Studies 30: 1024-54. [CrossRef]

Vertovec, Steven. 2010. Towards Post-multiculturalism? Changing Communities, Conditions and Contexts of Diversity. International Social Science Journal 61: 83-95. [CrossRef]

Steven Vertovec, and Susanne Wessendorf, eds. 2010. The Multiculturalism Back-Lash. New York: Routledge.

Vertovec, Steven. 2011. The Cultural Politics of Nation and Migration. Annual Review of Anthropology 40: 241-56. [CrossRef] 
Waddington, Lisa. 2011. Reasonable Accommodation Time to Extend the Duty to Accommodate Beyond Disability? NTMI NJCM-Bulletin 36: 186-98.

Whittington, Les, and Nicholas Keung. 2015. Stephen Harper Says Ottawa to Appeal Ruling Allowing Veil during Citizenship Oath. Available online: http:/ /www.thestar.com/news/canada/2015/02/12/stephen-harpersays-ottawa-to-appeal-ruling-allowing-veil-during-citizenship-oath.html (accessed on 29 September 2017).

Wilkins-LaFlamme, Sarah. 2015. How Unreligious are the Religious 'Nones'? Religious Dynamics of the Unaffiliated in Canada. Canadian Journal of Sociology 40: 477-500.

Williams, Joan C., and Nancy Segal. 2003. Beyond the Maternal Wall: Relief for Family Caregivers Who are Discriminated Against on the Job. Harvard Women's Law Journal 26: 77-162.

WIN-Gallup International. 2012. Global Index of Religiosity and Atheism. Zurich: WIN/Gallup International.

Winter, Elke. 2011. Us, Them and Others: Pluralism and National Identities in Diverse Societies. Toronto: University of Toronto Press.

Winter, Elke. 2015. Rethinking Multiculturalism After its "Retreat": Lessons from Canada. American Behavioral Scientist 59: 637-57. [CrossRef]

Woehrling, José. 1998. L'obligation d'accommodement raisonnable et l'adaptation de la société à la diversité religieuse. McGill Law Journal 43: 325-401.

Woodhead, Linda. 2017. The Rise of 'No Religion' in Britain: The Emergence of a New Cultural Majority. Journal of the British Academy 4: 245-61.

YouGov. 2016. YouGov/University of Lancaster Survey Results. Available online: https://d25d2506sfb94s. cloudfront.net/cumulus_uploads/document/m6imjuukrf/UniversityofLancasterResults_151222 ChurchBuildings_LifeStages_website.pdf (accessed on 29 September 2017).

Zuckerman, Phil. 2010. Society without God: What the Least Religious Nations Can Tell Us About Contentment. New York: NYU Press.

McGillivray, Kate. 2017. Pages torn from Qur'an at Peel School Board Meeting over Prayer Issue. CBC.ca. March 23. Available online: http://www.cbc.ca/news/canada/toronto/peel-school-board-muslim-prayer-space1.4038380 (accessed on 26 September 2017).

\section{Case Law and Legislation}

Alberta v Hutterian Brethren of Wilson Colony, 2009 SCC 37.

Canada (Citizenship and Immigration) v Ishaq, 2015 FCA 151.

Canadian Charter of Rights and Freedoms, R.S.C, 1985 Appendix II, No. 44 see also Part I (ss. 1 to 34) of the Constitution Act, 1982.

Erazo v Dufferin-Peel Catholic District School Board, 2014 ONSC 2072.

Ishaq $v$ Canada (Citizenship and Immigration), 2015 FC 156.

Multani v Commission scolaire Marguerite-Bourgeoys, 2006 SCC 6.

Mouvement lä̈que québécois v Saguenay (City), 2015 SCC 16.

S.L. v Commission scolaire des Chênes, 2012 SCC 7.

Sorgini v Simcoe Muskoka Catholic District School Board, 2017 HRTO 471.

(C) 2017 by the author. Licensee MDPI, Basel, Switzerland. This article is an open access article distributed under the terms and conditions of the Creative Commons Attribution (CC BY) license (http://creativecommons.org/licenses/by/4.0/). 